\title{
Tinjauan Teori Rekrutmen Pimpinan Daerah Dalam Dimensi Historis
}

\author{
Debi Setiawati ${ }^{*}$
}

\begin{abstract}
Abstrak
Kedudukan Kepala Daerah dipandang sebagai suatu posisi yang strategis dalam keberhasilan pembangunan nasional. Hal tersebut dipengaruhi oleh karena pemerintahaan daerah memilikin peran sebagai motor penggerak, kreator, inovator pemikiran dan perencanaan dalam pencapaian tujuan nasional yang merupakan subsistem dari pemerintah pusat. Oleh karena itu dalam perekrutannya perlu diterapkan adanya sistem demokrasi yang dapat memberikan peluang rotasi pejabat politik secara teratur dan damai.Di samping itu dengan melihat gambaran masyarakat Indonesia yang bersifat Plural dan Heterogen, maka dalam pelaksanaan PILKADA diserahkan secara otonom penuh daerah. Hal itu disebabkan karena yang mengetahui kebutuhan dan karekter pemimpin yang diingingkan masyarakat daerah itu sendiri.
\end{abstract}

\section{Kata kunci : Pimpinan Daerah, Demokratis, Pluralitas dan Heterogenitas}

\section{Pendahuluan}

Sejak masa pemerintahan kolonial Belanda sampai dengan masa orde baru kedaulatan rakyat dalam pilkada telah dimonopoli oleh elite politik. Rakyat tidak dapat memilih kepala daerah dan wakil kepala daerah secara langsung. Elite pusat dan daerah mempermainkan kedaulatan rakyat demi kepentingan pribadi atau kelompoknya. Pada masa reformasi fenomena tersebut dapat digantikan dengan adanya perubahan tata cara pemilihan daerah atau pilkada secara langsung.

* Debi Setiawati adalah Dosen Pendidikan Sejarah IKIP PGRI Madiun; Jl Setiabudi 85 Madiun.

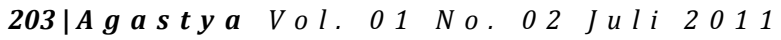


UU No. 32/2004 tentang pemerintahan daerah dan peraturan pemerintah No 6/2005 mengenai tata cara pemilihan, pengesahan, pengangkatan dan pemberhentian kepala daerah merupakan tonggak baru penegakan kedaulatan rakyat daerah di Indonesia. Kedua perundangan tersebut memuat ketentuan mengenai pemilihan kepala daerah dan wakil kepala daerah secara langsung.

Kepala daerah dan wakil kepala daerah, gubernur atau wakil gubernur, bupati atau wakil bupati,walikota dan wakil walikota, merupakan jabatan politik atau jabatan public. Jabatan tersebut di dalammnya memiliki mekanisme dan nilai-nlai demokaratis (terbuka dan akuntabel) dalam proses pemilihan, pertanggungjawaban tugas serta proses pemberhentian kepala daerah. Tata cara pemilihan kepala daerah dikatakan demokratis, apabila memenuhi beberapa kriteria. Terwujudnya kedemokratisan dalam pilkada dipengaruhi oleh adanya 4 kriteria yaitu:Pemilihan Umum, Rotasi Kekuasaan, Rekrutmen Terbuka dan Akuntabilitas Publik.

Rekrutmen jabatan politik atau publik dilaksanakan dengan pemilihan umum (PEMILU) yang diselenggarakan secara teratur dengan kurun waktu yang jelas, kompetitif dan jujur. Kekuasaan atau jabatan politik tidak boleh dan tidak bisa dipegang terus menerus oleh seseorang, seperti dalam sistem monarki.

Demokrasi membuka peluang untuk mengadakan kompetisi, sebab semua orang atau kelompok mempunyai hak dan peluang yang sama. Peluang tersebut terbuka bagi semua orang yang telah memenuhi syarat dengan kompetisi yang wajar sesuai dengan aturan yang telah disepakati. Para pemengang jabatan publik harus dapat mempertanggungjawabkan kepada publik apa yang dilakukan baik sebagai pribadi maupun sebagai pejabat publik.

Salah satu karakteristik pemimpin pemerintahan, khususnya Kepala Daerah adalah tanggap terhadap kondisi politik, baik dalam organisasi pemerintahan maupun dalam masyarakat. Selain itu juga harus dapat memberikan jawaban atau tanggapan atas kritik, saran dan pengawasan yang datangnya dari masyarakat. Seorang pemimpin juga harus tanggap terhadap kondisi kelembagan dalam arti memberikan perhatian serta tanggapan terhadap berbagai kebutuhan operasional demi kelangsungan kehidupan organisasi pemerintahan. Oleh karena itu seorang Kepala Daerah harus senantiasa memperhatikan kebutuhan dan kepentingan masyarakat serta organisasi (J.Kaloh,2010:6).

Tantangan yang dihadapi oleh Kepala Daerah dalam memimpin organisasi pemerintahannya anatara lain berupa bagaimana mewujudkan otonomi luas, bertanggung jawab, memiliki kualitas sumber daya aparatur yang optimal, sarana dan prasarana yang memadai, sumber alam dan sumber keuangan yang cukup besar, yang mampu meningkatkan dan mengembangkan kemampuan dan kehidupan masyarakat melalui program dan strategi 
pelayanan dan pem-berdayaan masyarakat.

Pasang surut kekuasaan nasional telah mempengaruhi pelaksanaan pilkada selama ini, yang disebabkan masing-masing penguasa atau rezim mengeluarkan kebijakan-kebijakan yang berbeda, yang dilatar belakangi oleh kepentingan pribadi atau kelompok. Hal tersebut mempengaruhi perubahan Landasan normatif penyelenggaraan pemerintahan daerah, sehingga dapat dilihat perbedaan pola kekuasaan, pola kegiatan penyelengaraan pemerintahan dan pola perilaku kepemimpinan dari waktu ke waktu yang terus mengalami perubahan. Pola sistem rekrutmen Pimpinan Daerah sangat menarik untuk dikaji lebih lanjut dari masa ke masa mengingat keberhasilan pembangunan nasional dan efektifitas penyelengaraan pemerintahan nasional dipengaruhi oleh kualitas kepemimpinan penyelengaraan pemerintah daerah.

\section{Arti Penting dan Tipe Pemimpin}

\section{Arti Penting Kepemimpinan}

Kepemimpinan merupakan kekuasaan untuk mempengaruhi seseorang, baik dalam mengerjakan sesuatu atau tidak mengerjakan sesuatu, bawahan dipimpin dari bukan dengan jalan menyuruh atau mendorong dari belakang. Pemimpin harus dapat memadukan kebutuhan dari bawahannya dengan kebutuhan organisasi dan kebutuhan masyarakat secara keseluruhannya, sehingga seorang pemimpin harus memiliki ketrampilan manajemen (menegerial skill) maupun ketrampilan teknis (technical skill). (Friska dalam Kepemimpinan Dalam Organisasi.http:www.eUSURepository @ 2004 Universitas Sumatera Utara).

Menurut Sarros dan Butchatsky (1996), pemimpin dapat diartikan sebagai suatu perilaku dengan tujuan tertentu untuk mempengaruhi aktivitas para anggota kelompok untuk mencapai tujuan bersama yang dirancang untuk memberikan manfaat individu dan organisasi. Sedangkan pendapat Anderson tentang kepemimpinan adalah : leadership means using power to influence the thoughts and actions of other in such a way that achieve high performance.

Pendapat senada juga diungkapkan oleh Stogdill (1974) dalam bukunya Handbook of Leadership bahwa kepemimpinan merupakan kepribadian yang memiliki pengaruh, sarana pencapaian tujuan dan berupa tindakan atau perilaku. Sedangkan Mitchell (1987) mengatakan bahwa kepemimpinan dipandang sebagai hubungan antarpribadi dimana seseorang individu berusaha mempengaruhi untuk melkaukan sesuatu. (J.Kaloh,2010:9)

Kepemimpinan berarti melibatkan orang atau pihak lain yaitu bawahan yang harus memiliki kemauan untuk menerima arahan dari pemimpin, sehingga seorang pemimpin yang efektif yang dengan kekuasaannya mampu mengungah bawahannya untuk mencapai tujuan yang akan dicapai secara optimal. 
Seorang pemimpin juga harus memiliki kejujuran terhadap diri sendiri (integrity), sikap bertanggung jawab yang tulus (compassion), pengetahuan (cognizance), keberanian bertindak sesuai dengan keyakinan (commitment), kepercaya-an pada diri sendiri dan orang lain (confidence) dan kemampuan untuk menyakinkan orang lain (communication) dalam membangun

organisasi.(http:www.anneahira.com motivasikepemimpinan.htm)

Kepemimpinan yang ideal harus didasari oleh adanya lima faktor yaitu: See the future (melihat masa depan), Engange and develop others (libatkan dan kembangkan orang lain), Reinvent Continuously ( temukan kembali terus menerus), Value Results and Relationship (hargai hasil dan hubungan), Embody the values (Mewujudkan Nilai).

See the future memiliki makna bahwa seorang pemimpin harus dapat menentukan arah perjalanan organisasi dan merencanakan tujuan bagi kemajuan organisasi. Sedangkan Engange and develop others memilki makna bahwa seorang pemimpin harus dapat memilih orang orang yang tepat untuk tugas yang tepat, sehingga bisa untuk menjadi pathner yang solid.

\section{Makna Reinvent Continuously} bagi seorang pemimpin adalah memiliki kreativitas dalam mengelola dan mengembangkan organisasi. Sedangkan untuk Value Results and Relationship dimaknai bahwa seorang pemimpin harus dapat melayani baik terhadap bawahan maupun pengikutnya. Embody the values dimaknai bahwa seorang pemimpin harus memiliki kredibilitas yang sangat tinggi baik secara internal maupun eksternal organisasi. (Blanchard,Miller dalam Priyoko Prayitnoadi Rahasia Kepemimpinan.http:wwwPriyoko.blo gsopt.com).

\section{Tipe Pemimpin}

G.R.Terry membagi tipe tipe kepemimpinan menjadi 6 yaitu :

a. Tipe kepemimpinan pribadi (Personal Leadership)

Segala seuatu tindakan dilakukan dengan mengadakan kontak, yang dilakukan secara lisan atau dilakukan secara pribadi oleh pemimpin yang bersangkutan.

b. Tipe kepemimpinan non pribadi ( Non Personal leadership)

Segala sesuatu kebijaksanaan yang dilaksanakan melalui bawahan bawahan atau media non pribadi baik rencana atau perintah juga pengawasan.

c. Tipe kepemimpinan otoriter (Autoritotian Leadership)

Pemimpin otoriter memiliki sifat pekerja keras , sungguh sungguh, teliti dan tertib. Ia bekerja menurut peraturan peraturan yang berlaku secara ketat dan instruksi instruksinya harus ditaati.

d. Tipe kepemimpinan demokratis (Democratis Leadership)

Pemimpin yang demokratis menganggap dirinya sebagai bagian dari kelompoknya dan bersama sama dengan kelompoknya berusaha bertanggung jawab, maka seluruh anggota ikut serta dalam segala kegiatan, perencanaan, penyelenggaraan, pengawasan dan penilaian. 
Setiap anggota dianggap sebagai potensi yang berharga dalam usaha pencapaian tujuan.

e. Tipe kepemimpinan paternalistis ( Paternalistis Leadership)

Kepemimpinan ini dicirikan oleh suatu pengaruh yang bersifat kebapakan dalam hubungan pemimpin dan kelompok. Tujuannya adalah untuk melindungi dan untuk memberikan arah seperti halnya seorang bapak kepada anaknya.

f. Tipe kepemimpinan menurut bakat (Indogenious Leadership)

Biasanya timbul dari kelompok orang orang yang informal dimana mungkin mereka berlatih dengan adanya sistem kompetisi, sehingga bisa menimbulkan klik klik dari kelompok yang bersangkutan dan biasanya akan muncul pemimpin yang mempunyai kelemahan diantara yang ada dalam kelompok tersebut menurut bidang ke-ahliannya dimana ia ikut berkecimpung.

Sedangkan menurut Kurt Lewin tipe kepemimpinan ada 3 yaitu :

a. Otokratis

Pemimpin yang memiliki sifat pekerja keras, sunguh sungguh, teliti dan tertib. Ia bekerja menurut peraturan yang berlaku dengan ketat dan instruksi instruksinya harus ditaati.

b. Demokratis

Pemimpin yang demokratis menganggap dirinya sebagai bagian dari kelompoknya dan bersama sama dengan kelompoknya berusaha bertanggung jawab tentang pelaksanaan tujuannya. Agar setiap anggota turut serta dalam setiap kegiatan kegiatan, perencanaan, penyelenggaraan, pengawasan dan penilaian. Setiap anngota dianggap sebagai potensi yang berharga dalam usaha pencapaian tujuan yang diinginkan.

\section{c. Laissezfaire}

Pemimpin yang bertipe demikian, setelah tujuan diterangkan pada bawahannya, untuk mneyerahkan sepenuhnya kepada para bawahannya untuk menyelesaikan pekerjaan pekerjaan yang menjadi tanggung jawabnya. Ia hanya akan menerima laporan laporan hasilnya dengan tidak terlampau turut campur tangan atau tidak terlalu mau ambil inisiatif, semua pekerjaan itu tergantung pada inisiatif dan prakarsa dari para bawahannya, sehingga dengan demikian dianggap cukup dapat memberikan kesempatan pada para bawahannya bekerja keras tanpa kekangan.

Dari beberapa tipe kepemimpinan diatas semua memiliki kelemahan dan kabaikannya masing masing. Oleh karena itu untuk penempatan tipe tersebut tergantung pada organisasi yang akan dipimpin. Disamping itu hasil kepemimpinan yang terbaik tidak dihasilkan dari satu macam tipe saja tetapi dapat dikombinasikan dari beberapa tipe kepemimpinan.

\section{Pluralisme}

Masyarakat Indonesia dengan kompleksitas kebudayaannya memiliki sifat plural (jamak) dan heterogen ( beraneka ragam). Hal tersebut dapat dilihat dari adanya sub kelompok masyarakat yang tidak dapat disatukelompokkan,sehingga masing masing memiliki karakteristik yang khas yang membedakan antara satu dengan yang lain. 
Identitas tersebut antara lain berupa suku, agama, ras, bahasa, struktur sosial, etnis, dll.

Koentjaraningrat mengemukakan bahwa bangsa Indonesia memiliki kurang lebih 500 suku bangsa baik suku bangsa besar maupun kecil. Sedangkan Van Vollenhoven mengemukakan bahwa di kepulauan nusantara dapat diidentifikasikan adanya 19 lingkungan hukum adat, yang kemudian diperluas oleh Dr.B. Ter Haar menjadi 24 lingkungan hukum adat. (Budiono kusumohadjojo, 2000:49).

Pluralitas dan heterogenitas dalam kehidupan masyarakat Indonesia masih dapat dikaji dari berbagai aspek kehidupan lainnya selain yang bersifat materi. Oleh karena itu pluralitas dan heterogenitas itu dapat dipahami sebagai suatu kekayaan dalam konteks keanekaragaman budaya. Di samping itu juga keanekaragaman ini dapat menjadi potensi munculnya nation bleeding apabila dieksploitasi secara sengaja.

$$
\text { Pada }
$$

Koentjaraningrat tahun

1970 bahwa potensi konflik antarsuku bangsa dan antargolongan yang berbeda beda di Indonesia akan menyusut dalam satu generasi. Akan tetapi dalam kenyataannya potensi konflik tersebut bukannya menyusut, justru benar benar terjadi.( Koentjaraningrat, 1992: 30).

Konflik antar SARA yang sering terjadi dalam masyarakat yang bersifat plural dan heterogen merupakan tantangan tersendiri yang harus dihadapi dengan nation building. Akan tetapi kenyataan yang ada dalam masyarakat Indonesia munculnya konflik sosial antara lain dipengaruhi oleh adanya sistem pengelolaan politik dan ekonomi yang masih bersifat sentralistik di tangan pemerintah pusat. Hal itu dipegaruhi oleh kenyataan historis bahwa pulau Jawa telah mmeperoleh reputasi sebagai pusat transit dan komunikasi semenjak penjajahan aisng pertama masuk Ke Indonesia, sehingga secara langsung kawasan politik, ekonomi dan budaya Indonesia berada di pulau Jawa.

(Budiono kusumohadjojo,2000:50).

Konsep negara kesatuan yang secara konsisten disertai dengan pemerintahan yang sentralistik terhadap suatu kondisi kebangsaan yang bersifat pluralistik dan heterogenitas telah menimbulkan ketertinggalan dan keterasingan dari kawasan yang jauh dari pemerintah pusat. Akan tetapi sistem desentralisasi juga tidak menjamin akan dapat mengatasi tantangan tersebut, justru muncul kekhawatiran bahwa budaya feodalisme dan koruptor ada di daerah daerah.

\section{Masa Kolonial Hindia Belanda}

Pada masa pemerintahan kolonial Hindia Belanda dalam pengangkatan kepala daerah dilakukan dengan sistem desentralisasi. Dikeluarkannya undangundang desentralisasi atau Decentralisatie Wet. Pada tahun 1903 bertujuan untuk mengalihkan sebagian dari kekuasaan dan kewenangan pemerintah pusat kepada derahdaerah. Namun kenyataannya hanya berupa peng-alihan dari kewenangan 
pembuat wet (uu) dan koninkljk (sk Kerajaan ) di S'Gravenhage ke pembuat ordonansi di Batavia.

Pada zaman Hindia Belanda pengaturan tentang pemerintahan di daerah dibedakan antara daerah Jawa dan Madura dengan daerah luar Jawa dan Madura sesuai dengan politik penjajahan. Pada masa Hindia Belanda terdapat dua birokrasi pemeritahan yang didasarkan atas Ras yaitu: BB (Binenlandsch bestuur) dan PP (Pangreh Praja) atau Insland Bestuur. Kedudukan Pangreh praja di sini bersifat hierarkis dan sentralistis mulai dari gewest (propinsi) yang dipimpin gubernur, karesidenan yang dipimpin residen, afdeling (asisten residen).

Pada tingkat pamong praja terdapat kabupaten (bupati), distrid atau kawedanan (wedana) dan onder district atau kecamatan (camat). Politik kolonial Belanda dalam menguasai daerah jajahan menerapkan sistem pemerintah daerah yang bertujuan untuk kepentingan mereka. Oleh sebab itu untuk daerah Jawa dan Madura atau daerah luar Jawa dan Madura, jabatan-jabatan gubemur, residen, asisten residen dan kontrolir dijabat oleh orang-orang Belanda, sedang untuk jabatan-jabatan lain dipegang oleh orang pribumi bangsa Indonesia. Untuk semua jabatan tersebut pilkada dilakukan dengan sistem penunjukan atau pengangkatan oleh penguasa kolonial atau tepatnya gubemur jenderal dengan kewajiban pribumi yang menduduki jabatan wajib memberikan kompensasi ekonomi (upeti) dan politik. Landasan yuridis pengangkatan jabatan-jabatn tersebut adalah diktum yang termaktub dalam pasal 6 Seksi Pajak Daerah dan 6b dan "desentralistie We" yakni dengan mempertimbangkan berbagai keadaan dan kemungkinan yang ada di daerah.

Dalam pengangkatan gubernur jendral juga telah memperhatikan Raad Van Indie. Akan tetapi suara Raad Van Indie selalu sama dengan gubernur jendral, sebab tata cara pemilihan Raad dilakukan melalui penunjukan dan pengangkatan sehingga komposisinya didominasi oleh orang-orang Eropa. Oleh karena itu dapat dikatakan bahwa pada masa Hindia Belanda, sesungguhnya kewenangan legislatif disubordinasi eksekutif.

Sedemikian tertutup rekrutmen pejabat kepala daerah pada saat itu sehingga mekanisme pemihan terdapat praktik KKN. Salah satu bentuk yang dilakukan penguasa kolonial adalah menunjuk kepala-kepala daerah dari kalangan raja-raja atau keluarga kerajaan untuk jabatan-jabatan yang "dialokasikan bagi pribumi". Penunjukkan kepala daerah tanpa syarat yang jelas dan hanya berdasarkan selera dan kepentingan politik dan ekonomi penguasa kolonial. Demikian pula dengan pemberhentian para kepala daerah yang pribumi diberhentikan apabila tidak menguntungkan kaum kolonial. Rekrutmen pejabat-pejabat daerah tersebut belum demokrasi dan jauh dari prinsip-prinsip keterbukaan dan akuntabilitas publik. 


\section{Masa Kolonial Jepang}

Pada masa kolonial Jepang pengangkatan atau penunjukkan kepala daerah dilakukan dengan sistem sentralisasi. Hal tersebut ditandai dengan dikeluarkannya $3 \mathrm{UU}$ antara lain UU No 27 tentang perubahan pemerintahan, UU No 28 tentang aturan pemerintahan syuu, UU No 30 tentang mengubah nama negeri dan nama daerah.

Menurut

Soetandyo

Wignjosubroto (2004) UU No 28 dipandang sebagai produk hukum pemerintah militer yang berkonsekuensi dan konsekuensinya berumur paling panjang, sehingga pembagian daerah di Indonesia tidak lagi didasarkan atas propinsi tetapi dalam bentuk karesidenan yang dikenal dengan syuu yang berjumlah 17 yang dikepalai oleh syuutyo. Di samping itu juga ada tokubetusi sebagai pengganti dari reggenschapen dan staadgemeenten, yang dikepalai oleh tokutebo-sityoo yang dijabat oleh kepala perwira Jepang.

UU No 27 memberi nama baru pada deregentschappen dan de stadsgemeenten yang dalam versi baru disebut ken dan si. Kedua daerah ini dikepalai oleh pembesar negara yang masing-masing disebut kentyo dan sityo. Sedangkan kepala daerah disebut dengan guntyoo, santyoo dan kuntyoo. Secara tradisional jabatan-jabatan tersebut selalu dipegang oleh orang-orang pribumi Indonesia.

Menurut pendapat I Kaloh bahwa pemerintah kolonial Jepang masih mempertahankan asas dekonsentrasi dengan sedikit variasi perubahan nama-nama daerah beserta jabatannya digantikan oleh pembesar-pembesar Jepang, sedangkan bangsa Indonesia hanya diberi kesempatan sedikit. Hal itu terlihat dengan dihapuskannya wilayah propinsi beserta gubernurnya, afdeling beserta asisten residen dihapuskan di daerah Jawa dan luar Jawa.

Sistem rekruitmen kepala daerah mengabaikan nilai-nilai demokrasi, transparansi dan akuntabilitas, sebab diangkat dan ditunjuk oleh penguasa, Jepang. Sistem pengangkatan atau penunjuk-kan bersifat hierarkis serta memotong struktur hierarkinya.

\section{Masa Kemerdekaan}

\section{Masa Orde Lama UU No 1 tahun 1945}

UU No 1/1945 memuat tentang peraturan mengenai kedudukan komite nasional daerah. UU ini bersifat sementara sembari menunggu diselenggaarakan Pemilu. UU ini sangat penting untuk menampung semangat kedaulatan rakyat yang sedang bekorbar, mengubah status quo pemerintah daerah dan mengubah komite nasional Indonesia daerah menjadi badan perwakilan rakyat daerah dengan dasar kedaulatn rakyat.

Fungsi dari kepala daerah dalam UU ini sebagai lembaga eksekutif serta legislatif, yang mana memiliki tugas menjalankan fungsi eksekutif sebagai pemimpin nasional daerah, kepala daerah juga menjadi anggota dan ditetapkan sebagai ketua legislatif dalam BPR daerah. 
Kepala daerah di sini diangkat pada masa sebelumnya sebab situasi politik, keamanan dan hukum ketatanegaraan tidak menentu, sehingga mereka diangkat begitu saja. Untuk menjaga kelangsungan pemeritah daerah sebagai bagian dari pemerintah pusat yang tergabung dalam NKRI.

\section{UU No 22 tahun 1948}

Berisi tentang pokok-pokok pemerintahan di daerah yang menunjuk pada pasal 18 UUD 45 tentang pemerintahan daerah yang berhak mengurus dan mengatur rumah tangga sendiri. UU ini lebih lengkap dan rinci termaksud mencantumkan ketentuan mengenai kepala daerah yang mencangkup pengisian, tugas dan tanggungjawab.

Sesuai dengan UU ini yang dimaksud kepala daerah adalah kepala daerah provinsi yang diangkat oleh Presiden, Menteri Dalam Negeri atau Gubemur atas usul DPR. Kepala daerah Provinsi atau Gubemur diangkat oleh Presiden. Adapun Kepala Daerah desa atau kota kecil diangkat oleh gubernur.

Fungsi dari kepala daerah ada 2 yaitu; sebagai pegawas (pekerjaan) DPRD yang berarti merupakan wakil pemerintah. Selain itu kepala daerah sebagai Ketua DPD yang berarti alat (organ) pemerintah daerah.

\section{UU No 1 tahun 1957}

UU ini berisi tentang pokok-pokok pemerintahan daerah yang didasarkan pada RIS dengan UUD sementara 1950 yang memuat tentang mekanisme pemilihan, penetapan, pelantikan dan persayaratan serta sumpah dan janji kepala daerah. Fungsi dari kepala daerah sebagai ketua dan anggota pemerintahan daerah yang menjalankan roda pemerintahan.

Kepala daerah dipilih oleh DPRD dengan mempertahatikan syaratsyarat kecakapan dan pengetahuan yang diperlukan dalam jabatan tersebut. Perekrutan melalui pemilihan secara langsung dari rakyat yang disampaikan melalui DPRD dapat dikatakan lebih demokratis karena dilakukan secara langsung.

\section{Penetapan Presiden No 6 tahun 1959}

Penetapan Presiden No 6/1959 ini dilengkapi dengan penetapan presiden No 5/1960 tentang DPRGR dan sekretariat daerah yang berisi tentang mengatur mekanisme dan prosedur pengangkatan kepala daerah yang menyangkut Gubernur dan Bupati/Walikota.

Kepala daerah dingkat dan diberhentikan oleh Presiden atau Menteri dalam negeri dari calon yang diusulkan DPRD. Namun Presiden atau Menteri dalam negeri dan otonomi daerah boleh menetapkan pengangkatan di luar pencalonan dengan kriteria pendidikan, kecakapan dan pengalaman dalam pemerintahan. Kepala daerah memiliki fungsi sebagai alat pemerintahan pusat dan daerah.

\section{UU No 18 tahun 1965}

Dalam UU ini kepala daerah diangkat dan diberhentikan oleh Presiden atau Menteri dalam negeri, sekalipun yang mengajukan calonnya adalah DPRD. UU ini berisi tentang persyaratan seseorang untuk diangkat sebagai kepala daerah dengan masa jabatan 5 tahun dan dapat dipilih kembali. Dominasi pemerintah pusat untuk mengadakan 
daerah semakin terlihat ketika kedudukan kepala daerah ditetapkan sebagai pegawai negara, yang pengaturannya berdasarkan peraturan pemerintah.

\section{Masa Orde Baru}

Pada masa orba sistem pilkada diatur dalam UU No 5/1974 tentang pokokpokok pemerintahan daerah yang lalu dan digunakan pada masa pemerintahan Presiden Soeharto. UU ini mengatur tentang syarat kepala daerah, mekanisme pengisian, kewenangan kepala daerah, hubungan kepala daerah dengan DPRD, mekanisme pengangkatan dan pemberhentian kepala daerah, masa jabatan dan sebagainya.

Kepala daerah bertanggung jawab kepada Presiden melalui menteri dalam negeri, sebab yang memilih dan yang mengangkat adalah Presiden. Presiden dalam menetapkan calon terpilih memiliki kewenangan untuk mengabaikan hasil pemilihan DPRD, sebab tidak terikat pada jumlah suara yang diperoleh masing-masing calon, sebab hal itu merupakan hak prerogratif Presiden.

Menurut pendapat Afan Gaffar rekrutmen politik lokal ditentukan sepenuhnya oleh pemerintah pusat, khususnya pejabat dalam negeri untuk pengisian jabatan Bupati, Walikota, Sekretaris daerah dan kepala-kepala dinas di provinsi. Sementara untuk jabatan Gubernur ditentukan oleh Departemen Dalam Negeri, markas besar TNI dan sekretariat negara.

\section{Masa Reformasi}

Reformasi membawa perubahan dalam pilkada dengan dikeluarkannya. UU No 22/1999 tentang otonomi daerah yang mengangkat tentang ketentuan tugas, fungsi dan kewengangan DPRD dalam pelaksanaan Pilkada. Ketentuan lebih rinci tentang pilkada dalam peraturan pemerintah No 151/2000 tentang tatacara pemilih-an, pengesahan dan pemberhentian kepala daerah dan wakil kepla daerah tahapantahapannya antara lain: Pendaftaran bakal calon, Penyaringan bakal calon, Penetapan pasangan calon, Rapat paripurna khusus, Pengiriman berkas pen-daftaran dan pengesahan, Pelantikan.

Semua tahapan itu dirancang agar kepala daerah yang terpilih benar-benar yang mumpuni yaitu: memenuhi kualifikasi administrative yang disyaratkan, mengenal dan dikenal masyarakat daerah, memiliki kompetensi dan kapabilitas memimpin daerah serta memiliki visi dan misi serta strategi membangun daerah.

Kepala daerah dipilih dengan sistem perwakilan melalui DPRD dari berbagai varian sistem pemilihan perwakilan ini, ditentukan sejumlah ciri penting yaitu: Mekanisme pemilihan terbuka, Akses masyarakat untuk berpartisipasi dan melakukan kontrol terbuka secara terbatas, Partai mulai berperan penting, khususnya dalam tahap penjaringan calon, DPRD melakukan pemilihan, DPRD dapat meminta pertanggungjawaban kepala daerah, penetapan 
calon terpilih menggunakan sistem mayoritas sederhana (simple mayority), calon yang memperoleh suara terbanyak,Pejabat pusat hanya mengesahkan.

Dalam UU ini kedudukan kepala daerah sebagai pimpinan ekskutif baru sangat proporsional, yang mana kedudukan gubernur dan Bupati/Walikota sebagai kepala eksekutif disamping itu juga menjalankan fungsi sebagai wakil pemerintah pusat. Sedangkan bupati/walikota menjadi penanggungjawab pelaksanaan otonomi daerah. Dengan keddudukan seperti itu pemisahan antara eksekutif dan legislative terlihat jelas, sehingga mekanisme check and balances bisa berfungsi lebih optimal.

\section{Pembahasan}

Kedudukan Kepala Daerah dipandang sebagai suatu posisi yang strategis dalam keberhasilan pembangunan nasional. Hal tersebut dipengaruhi oleh karena pemerintahaan daerah merupakan subsistem dari pemerintahan nasional. Keberhasilan kepemimpinan di daerah menentukan kesuksesan kepemimpinan nasional, sebaliknya ketidakmampuan Kepala Daerah dalam menyukseskan pembangunan nasional akan mempengaruhi rendahnya kualitas dan efektivitas penyelenggaraan pembangunan nasional. Untuk itu kedudukan Kepala Daerah sebagai pemimpin pemerintahan di daerah berperan sebagai motor penggerak, kreator, inovator pemikiran, perencanaan, evaluasi dan pengendalian berbagai kebijakan dalam pencapaian tujuan nasional.

Diharapkan dengan sistem demokrasi dapat memberikan peluang rotasi kekusasaan atau rotasi pejabat politik secara teratur, damai dari seorang kepala daerah yang satu ke kepala daerah yang lain, dari satu partai politik ke partai yang lain.

Pasang surut demokrasi dalam pemilihan kepala daerah dapat dikatakan bahwa pelaksanaaan pilkada yang dilakukan di Indonesia sejak masa kolonial sampai dengan masa Reformasi dilakukan melalui sistem tertutup. Sebab dalam pengisian jabatan politik hanya melibatkan sekelompok kecil kalangan elite. Pilkada yang telah dilaksanakan di Indonesia bersifat tertutup sebab hanya memberikan peluang kepada sekelompok elite, baik sebagai calon pemilih maupun memilih. Sedangkan sistem yang digunakan dalam pelaksanaan Pilkada dilakukan secara tidak langsung. Sejak masa pemerintahan kolonial hingga masa reformasi menggunakan cara tidak langsung yaitu Pilkada yang tidak membuka akses bagi warga secara langsung baik sebagai pemilih, calon maupun pengawal proses pelaksanaan.

Dalam pelaksanaan Pilkada secara tidak langsung yang ada di Indonesia dapat digolongkan menjadi 3 jenis yang memiliki karakteristik tersendiri yaitu: Penunjukkan dan pengangkatan oleh pemerintah pusat, yang memiliki karakteristik tersendiri-tersendiri. Hal ini nampak dari pola kepemimpinan pusat dengan daerah antara lain : Kekuasaan dan kewenangan pejabat 
pusat sangat besar, Kepala daerah dijadikan sebagai alat pemerintah pusat, Peranan DPRD sangat kecil, Tatacara pelaksanaan Pilkada sangat tertutup, DPRD tidak bisa meminta per-tanggungjawaban kepala daerah atau sebaliknya kepala daerah bertanggung jawab pada pemerintah pusat.

Pemilihan perwakilan semu yaitu dalam pelaksanaan. Pilkada seolah-olah dilakukan DPRD, namun sebagai penentunya adalah pejabat pusat seperti Presiden, Menteri dalam negeri dan. Gubemur yang memiliki karakteristik: Pelaksanaan Pilkada seakan-akan bersifat demokratis, Kekuasaan dan kewenangan pemerintah pusat sangat besar, Kepala daerah bertanggungjawab pada pemerintah pusat, DPRD memiliki peran terbatas, Partisipasi rakyat sangat terbatas.

Pemilihan oleh DPRD yaitu Pengisian jabatan kepala daerah yang memenuhi syarat sebagai pemilihan adalah berdasarkan pelaksanaan Pilkada berdasarkan UU No 22/1999, yang mana kepala daerah dipilih dengan sistem perwakilan melalui DPRD, yang memiliki beberapa ciri antara lain: Pemilihan bersifat terbuka, DPRD melakukan pemilihan, Pejabat pusat hanya mengesahkan, Partai politik mulai berperan penting dalam perekrutan calon, DPRD dapat meminta pertanggungjawaban kepala daerah.

Praktik Pilkada yang berlaku di Indonesia selama ini mengalami penyimpangan demokratis, tetapi di satu sisi membuka peluang intervensi pemerintah pusat dan sentralisasi kekuasaan. Ada beberapa kelemahan pelaksanaan Pilkada secara langsung antara lain:

a. Menutup pendidikan politik bagi masyarakat.

Keterbatasan informasi politik mengakibatkan jarak antara masyarakat dan kepala daerah semakin jauh, sehingga menyebabkan masyarakat kurang berpartisipasi dalam bidang politik.

b. Kepekaan kepala daerah terhadap kebutuhan yang diperlukan oleh masyarakat berkurang

Dalam Pilkada tidak langsung kepala daerah sangat tergantung pada pemerintah pusat atau DPRD, sehingga mereka kurang memperhatikan hal-hal yang dibutuhkan rakyat.

c. Tidak adanya mekanisme pemilihan kompetitif, jujur dan adil

Pilkada tidak langsung identik dengan ruang kompetisi yang tidak kompetitif, jujur dan adil sehingga mempersempit rotasi kekuasaan, akibatnya jabatan kepala daerah dipegang secara terus menerus oleh seseorang atau partai politik tertentu. d. Menutup kepemimpinan daerah

Hanya mereka yang dekat dengan pemerintah atau pejabat pusat atau DPRD yang memiliki kesempatan dan peluang memenangkan kompetisi.

e. Mengabaikan kesetaraan politik (political equality)

Pilkada tidak langsung mendiskriminasikan hak-hak politik masyarakat dalam arti menolak terwujudnya kesetaraan politik diantara berbagai komponen dalam masyarakat.

f. Lemahnya akuntabilitas publik 
Pilkada tidak langsung menimbulkan akuntabilitas kepala daerah kurang di masyarakat, sebab kepala daerah cenderung tidak accensible atau tidak bertanggungjawab terhadap pendudduk setempat, sehingga akan mengabaikan pertanggungjawaban terhadap berbagai kebijakan dan hasil-hasilnya. Kepala daerah juga tidak dapat menunjukkan tanggungnya sebagai pribadi dan pejabat publik.

Di samping itu pelaksanaan Pilkada di Indonesia yang dilakukan secara tidak langsung, di sisi lain juga memiliki kelebihan antara lain:

a. Tidak membutuhkan dana atau biaya besar

Dana yang dibutuhkan untuk Pilkada tidak langsung sangat kecil dibandingkan dengan dana yang dibutuhkan untuk Pilkada langsung. Di samping itu juga dana yang dikeluarkan calon dalam pemilihan tak langsung lebih sedikit daripada pemilihan langsung, khususnya untuk kampanye dan kegiatan politik lain.

b. Masyarakat terhindar dari konflik

Pemilihan tidak langsung dapat menghindarkan konflik antar pendukung calon kepala daerah, sebab jika dilakukan secara langsung akan memberikan peluang yang sangat besar terjadinya konflik antar pedukung, yang mana karakteristik masyarakat Indonesia yang paternalistic dan primordial, terutama pada masa kampanye.

c. Masyarakat tidak dibingungkan oleh kegiatan-kegiatan politik

Dalam Pilkada masyarakat tidak disibukkan oleh kegiatan-kegiatan politik seperti kampanye, sehingga tidak menggangu kegiatan mereka seperti bekerja dan sekolah.

Oleh karena itu dapat ditarik satu kesimpulan bahwa pelaksanaan Pilkada di Indonesia masih jauh dari nilai-mlai demokratis, transparansi dan akuntabilitas. Akan tetapi dalam pelaksanaanya yang dilakukan dengan sistem tidak langsung memiliki beberapa kelemahan, tetapi di satu sisi memiliki kelebihan. Untuk itu dalam pemilihan sistem pelaksanaan Pilkada di Indonesia disesuaikan dengan karakteristik dan kondisi politik masyarakat Indonesia sebab semua sistem pemilihan memiliki kelemahan dan kelebihannya tergantung bagaimana kita mengurangi kelemahan itu dan memperkuat kelebihannya.

\section{Penutup}

Pelaksanaan Pilkada yang dilakukan di Indonesia sejak masa pemerintahan kolonial sampai dengan masa reformasi dapat dikatakan masih jauh dari sifat kedemokratisan, tidak transparan dan tidak memiliki nilai akuntabilitas yang tinggi. Untuk itu perlu adanya pembaharuan maupun perubahan baik secara hukum maupun dalam praktik atau pelaksanaanya. Dalam pembaharuan tersebut perlu dicari sistem atau bentuk yang sesuai dengan kondisi masyarakat Indonesia yang bersifat plural atau majemuk, yang memiliki beraneka ragam budaya serta wilayah Indonesia yang sangat luas. Di samping itu juga disesuaikan dengan kondisi kehidupan politik masyarakat 
Indonesia, sebab kondisi politik inilah yang akan menjadi bingkai dalam pelaksanaan Pilkada.

Dengan melihat gambaran masyarakat Indonesia yang bersifat plural atau majemuk. Maka sebaiknya dalam pelaksanaan Pilkada diserahkan secara otonomi kepada daerah sebab yang mengetahui akan kebutuhan yang diperlukan oleh masyarakat di daerah adalah pemerintah daerah setempat. Di samping itu dalam memilih calon kepala daerah diberikan kebebasan penuh kepada daerah, sebab yang mengetahui karakter pemimpin yang diinginkan masyarakat daerah adalah pemerintah daerah sendiri. Oleh karena itu yang wajib melakukan pelaksanaan Pilkada adalah pemerintah daerah yaitu DPRD, sedangkan pemerintah pusat hanya mengesahkan saja sebagai lembaga yang memiliki hierarkis tertinggi dalam pemerintahan di Indonesia.

Sistem pemilihan yang dirasa cocok dengan kondisi masyarakat Indonesia adalah sistem terbuka dalam perekrutan calon kepala daerah yaitu semua warga negara yang memenuhi syarat tertentu seperti umur, kemampuan atau kecakapan, pendidikan dan pengalaman dalam pemerintahan memiliki peluang yang sama untuk mengisi jabatan politik. Dengan demikian terbuka peluang untuk melibatkan dan membuka partisipasi seluruh warga masyarakat yang memenuhi syarat sebagai pemilih dan terbuka kemungkinan sebagai calon serta, pengawal proses pelaksanaan. Sebab selama ini yang telah dilakukan adalah sistem tertutup yang hanya memberikan kesempatan bagi elite tertentu saja.

Akan tetapi dalam pelaksanaannya dengan menggunakan gabungan antara langsung dengan tidak langsung dengan jenis pemilihan oleh DPRD. Dalam pemilihan ini calon kepala daerah telah dipilih oleh DPRD melalui seleksi dan dari calon-calon tersebut disosialisasikan kepada masyarakat setempat sebelum diadakan Pilkada, agar masyarakat mengenal dan mengetahui program-program yang nantinya akan dibuat, sehingga pada saat memilih masyarakat tidak mengalami kebingungan karena tidak tahu. Dan hasil pemilihan itu nantinya harus bersifat transparan terhadap masyarakat sehingga mereka dapat mengetahui secara jelas hasil dari Pilkada. Kemudian dari hasil pemilihan itu disahkan oleh pemerintah pusat.

Adapun kelebihan dari pelaksanaan pemilihan secara langsung dengan otonomi daerah antara lain: mekanisme pemilihannya bersifat terbuka, masyarakat dapat berpartisipasi aktif dalam kehidupan politik, partai memiliki peran penting sebagai tempat menampung aspirasi rakyat, penetapan calon dengan menggunakan mayoritas sederhana atau berdasarkan suara terbanyak, pejabat pusat tidak memiliki campur tangan yang besar karena hanya mengesahkan saja, DPRD dapat menjalankan tugas dan tanggungjawabnya secara penuh, serta DPRD dapat meminta pertanggungjawaban dari kepala daerah. Sedangkan kelemahnnya antara lain mem- 
butuhkan dana terlalu besar, masyarakat disibukkan dengan berbagai kegiatan politik seperti kampanye, membutuhkan waktu yang lama dan kemungkinan bisa memicu munculnya konflik antar pendukung, sebab terjadinya per-saingan terutama dalam kampnye.

Dilihat dari kondisi masyarakat Indonesia yang majemuk serta wilayahnya yang sangat luas, maka pelaksanaan Pilkada yang cocok untuk dilaksanakan adalah bersifat otonomi penuh daerah sedangkan pemerintah pusat hanya mengesahkan. Sebab yang mengetahui karakter pemimpin yang diinginkan oleh masyarakat dan yang mengetahui kebutuhan yang diperlukan oleh masyarakat daerah adalah pemerintah daerah yaitu DPRD. 


\section{Daftar Pustaka}

Bakker, J.W.M. 1994. Filsafat Kebudayaan : Sebuah Pengantar. Yogyakarta : Kanisius

Budiono Kusumohamidjojo, 2000. Kebhinekaan Masyarakat di Indonesia. Jakarta : Grasindo

Furnivall J.S., 1994. Netherlands India (astudy pf plural economy). Cambridge at the University Press.

Koentjaraningrat. 1992. Beberapa Pokok Antropologi Sosial, Jakarta : Penerbit Dian Rakyat

Sutherland, 1996. Terbentuknya Elite Birokrasi. Yogyakarta: Pustaka Pelajar

Werthein, 1990. Masyarakat Indonesia dalam Transisi Studi Perubahan Masyarakat Indonesia. Yogyakarta: Tiara Pelajar.

J.Kaloh, 2010. Kepemimpinan Kepala Daerah ( Pola kegiatan, Kekuasaan dan Perilaku Kepala Daerah Dalam Pelaksanaan Otonomi Daerah).Jakarta : Sinar Grafika

Mitfah Thofa, 1986. Kepemimpian Dalam Menegement. Jakarta : Rajawali
Mubyarto, 2000. Otonomi atau Federalisme. Jakarta : Sinar Harapan

Simandjuntak, Marsillam, 1994. Pandangan Negara Integralistik. Jakarta : Grafitti

Syafrudin, Ateng. 1983. Pasang Surut Otonomi Daerah. Bandung : Bina Cipta

Soemitro Rahmat. 1983. Peraturan Perundang Undangan Tentang Pemerintahan Daerah. Bandung : Eresco Terate

Pamudji, 1985. Kepemimpinan Pemerintahan di Daerah. Jakarta : Bumi Aksara

Poespowardojo, Soerjanto.1989. Strategi Kebudayaan, Suatu Pendekatan Filosofis.Jakarta : Gramedia 